\title{
ISLAM DAN PERGERAKAN CIVIL SOCIETY KEBUDAYAAN TRANSNASIONAL HIZMET DI INDONESIA
}

\author{
Ozi Setiadi \\ SekolahTinggi Agama Islam Nurul Iman \\ Jl. Nurullman No. 1 Ds. Warujaya Rt. 01/01 Kec.ParungKab. Bogor \\ Email: ozisetiadi@ymail.com
}

\begin{abstract}
Islam and Civil Society Movement of Transnational Hizmet Culture in Indonesia. Hizmet movement in Indonsia as one Muslim civil society. First, the Hizmet movement in Indonesia as a transnational civil society movement that carries the Islamic themes emerged and developed in Indonesia using a cultural approach as their collective agenda. Second, is the Hizmet movement ideology (services), which adopts the ideology of Islamic values. The existence of this growing movement and can be seen from the distribution that have established humanitarian agencies in major cities in Indonesia. It became the Hizmet movement efforts in building a civil society in Indonesian culture, and to prove that Islam is in line with the civil society.
\end{abstract}

Keywords: Islam, Civil Society, Hizmet, Culture

Abstrak: $\quad$ Islam dan Pergerakan Civil Society Kebudayaan Transnasional Hizmet di Indonesia. Gerakan Hizmet di Indonesia sebagai suatu masyarakat madani Muslim. Pertama, gerakan Hizmet di Indonesia sebagai gerakan masyarakat sipil transnasional yang mengusung tema Islam muncul dan berkembang di Indonesia dengan menggunakan pendekatan budaya sebagai agenda kolektif mereka. Kedua, adalah ideologi gerakan Hizmet (jasa), yang mengadopsi ideologi nilai-nilai Islam yang mempromosikan ketidaktahuan, kemiskinan, dan konflik sebagai musuh bersama yang harus diperjuangkan. Ketiga, ketidaktahuan, kemiskinan, dan konflik menjadi referensi terpisah dari gerakan Hizmet dalam melakukan pelayanan untuk gerakan kemanusiaan. Adanya gerakan yang berkembang ini dan bisa dilihat dari adanya pendistribusian lembaga kemanusiaan di kota-kota besar di Indonesia. Ini menjadi upaya gerakan Hizmet dalam membangun masyarakat sipil dalam budaya Indonesia, dan untuk membuktikan bahwa Islam sejalan dengan masyarakat sipil.

Kata kunci: Islam, Masyarakat Sipil, Hizmet, Budaya 


\section{Pendahuluan}

Civil society adalah sebuah konsep yang lahir dari dunia barat pada abad kedua puluh. Ia menjadi sebuah konsep yang terlahir belakangan, setelah konsep pemerintahan yang fenomenal dan dianggap sebagai sebuah konsep yang terbaik saat ini yaitu demokrasi. Meski terlahir belakangan, bukan berarti bahwa civil society mudah diterima oleh berbagai kalangan. Asal-usulnya yang bermula dari Barat memberikan pandangan yang tersendiri bagi umat Muslim. Islam sebagai agama universal dan dianut oleh sepertiga penduduk dunia menjadi salah satu agama yang dianggap paling berpeluang dalam menanggapi hal ini. Hal ini disebabkan sebagai agama yang bersifat menyeluruh dan melingkupi semua aspek kehidupan, Islam dianggap memiliki kesamaan konsep dengan civil society. Akan tetapi, anggapan kesamaan konsep ini tidak berjalan dengan mulus karena adanya perbedaan pandangan antara satu kalangan umat Muslim dengan umat Muslim yang lain.

Kalangan yang menolak keras konsep civil society adalah umat Muslim yang berpandangan fundamental. Mereka menganggap bahwa Islam adalah agama yang kompleks yang mengajarkan semua aspek kehidupan, sehingga tidak memerlukan konsep lain seperti civil society. Lebih lagi civil society merupakan konsep yang berasal dari Barat, sehingga menurut kelompok ini tidak layak dianut sebagai sebuah sistem yang mensejahterakan. Masyarakat Barat yang notabene beragama selain Islam menjadi sebuah alasan. Doktrin Islam yang secara normatif menyebutkan bahwa terdapat sekelompok umat beragama tertentu yang tidak akan pernah menyukai umat Muslim sampai umat ini mengikuti apa yang mereka kerjakan adalah alasan yang memperkuat kalangan fundamentalis dalam menolak ajaran-ajaran Barat. Apalagi sumber-sumber normatif Islam, yaitu Al-Quran dan Hadis, dianggap suci dan sudah baku, maka tidak membutuhkan penginterpretasian kembali, bahkan oleh kalangan Barat. Oleh sebab itu,civil society dianggap tidak akan mungkin sesuai dengan Islam, bahkan menurut kelompok ini Islam dan civil society memang wajib bertentangan. ${ }^{1}$

Kelompok lain berpendapat berbeda, bahwa Islam tetap saja memiliki

${ }^{1}$ Sukron Kamil, Pemikiran Politik Islam Tematik: Agama dan Negara, Demokrasi, Civil Society, Syariah dan HAM, Fundamentalisme dan Anti Korupsi (Jakarta: Kencana, 2013), h.128. 
nilai-nilai yang dapat disandingkan dengan civil society. Menurut kelompok ini, meski civil society berasal dari Barat, akan tetapi dalam Islam juga terdapat hal yang serupa. Fahmi Huwaidi megemukakan bahwa civil society merupakan antitesis dari masyarakat Muslim, yang mana negaranya harus negara Islam. ${ }^{2}$ Civil society bila dalam istilah Barat, maka dalam istilah kalangan Muslim terdapat al-mujtamá al-madani atau masyarakat Madani. Ini membuktikan bahwa dalah Islam juga berbicara mengenai civil society. Cendikiawan Muslim awal, seperti al-Mawardi, al-Farabi, Ibn Thaimiyah dan lainnya juga berbicara tentang civil society, meski mereka berbicara pada konteks kepemimpinan saja. Hal ini menyebabkan civil society sebagai sebuah konsep yang modern dipandang hanya dengan satu sisi saja, sehingga melupakan dimensi yang lain. Oleh sebab itu, Fethullah Gülen mengemukakan bahwa apabila terdapat salah satu atau sekelompok orang yang unggul atas kelompok yang lain, mereka tidak dapat dikatakan mewakili Islam secara keseluruhan, ${ }^{3}$ karena Islam tidak dapat dilihat dari satu aspek saja, begitu pula dalam melakukan pandangan melalui kacamata Islam terhadap civil society.

Pergerakan hizmet adalah salah satu pergerakan civil society Muslim yang menggunakan Islam sebagai landasan dalam menjalankan pergerakan mereka. Pergerakan ini diinspirasi oleh Muhammed Fethullah Gülen dan melakukan pergerakan melalui aspek kebudayaan. Kemiskinan, kebodohan, dan konflik menjadi alasan utama bagi pergerakan ini untuk menjalankan pelayanan bagi umat manusia. Fokus pergerakan yang menyangkut nilai-nilai dan kepentingan komunal menjadikan pergerakan ini sebagai civil society yang bersifat kebudayaan. Oleh sebab itu, tulisan ini akan menjelaskan bahwa terdapat pandangan yang berbeda dalam memahami civil society, sehingga civil society yang oleh kalangan cendikiawan Muslim klasik dilihat sebagai sebuah konsep yang sangat dekat dengan negara, pada kenyataannya juga menjadi konsep yang mandiri dari negara. Lebih lanjut,

${ }^{2}$ Fahmi Huwaidi, Demokrasi dan Masyarakat Madani, terjemahan dari al-Islam wa al-Dimu Qrathiyyah, (Bandung: Mizan, 1996), 294, dalam Sukron Kamil, Pemikiran Politik Islam Tematik, h. 126.

${ }^{3}$ Lebih lanjut Gülen mengatakan bahwa masyarakat Islam terjebak pada lingkaran setan. Mereka mengulangi kesalahan yang sama tanpa bisa berhasil menemukan jati diri mereka sesungguhnya. Keberhasilan yang mereka peroleh satu langkah, di susul dengan kemunduran beberapa langkah dengan berbagai penyimpangan terhadap jalan yang lurus. Baca lebih lanjut dalam M. Fethullah Gülen, Bangkitnya Spriritualitas Islam, terj. Fuad Saefuddin(Jakarta: Republika, 2012), h. 20-25. 
tulisan ini akan membantah kelompok fundamentalis yang beranggapan bahwa Islam tidak sejalan dengan civil society.

\section{Konsep Civil Society}

Civil society sudah dikenal sejak abad ke-18 dalam tradisi Eropa dengan berbagai macam istilah, seperti koinonia politike dalam bahasa Yunani, societas civilis dalam bahasa Latin, societe civile dalam bahasa Perancis, dan burgerliche gesellchaft dalam bahasa Jerman, semuanya mensinonimkan pengertian civil society dengan negara. ${ }^{4}$ Beberapa pemikir Barat mengemukakan pendapat yang berbeda mengenai civil society. Hegel (1770-1831) berpendapat civil society adalah ruang yang menghubungkan antara negara dan masyarakat.. Sedangkan Ernest Gellner (1925-1995) mengemukakan bahwa civil society merupakan sebuah masyarakat maupun institusi di luar pemerintah yang tidak memiliki hubungan secara terstruktur dan terikat, melainkan berdiri sendiri dan otonom, sehingga memiliki kekuatan untuk mengimbangi negara. ${ }^{6}$

Nurcholis Madjid lebih menggunakan istilah masyarakat madani dalam memahami civil society. ${ }^{7}$ Menurutnya masyarakat Madani adalah

${ }^{4}$ J. Keane, Civil Society and the State (London: Verso, 1988), 35-36, dalam Bachtiar Alam, "Antropologi dan Civil Society: Pendekatan Teori Kebudayaan," Antropologi Indonesia Th. XXIII No. 60 (September-Desember 1999), h.194.

${ }^{5}$ Konsep ini juga dikemukakan oleh Habermas yang berpendapat bahwa ruang publik terletak di antara negara dan masyarakat dalam bentuk jaringan untuk bertukar informasi dan cara pandang. Jürgen Habermas, Between facts and norms: Contributions to a discourse theory of law and democracy (Cambridge: MIT Press, 1996). 360 dalam Muhammad Zubair Khan, dkk., "From Habermas Model to New Public Sphere: A Paradigm Shift," Global Journal of Human Social Science Volume 12 Issue 5 Version 1.0 (Maret 2012), 44, http://socialscienceresearch.org/index.php/GJHSS/ article/view/312/271 (diakses pada tanggal 31 Desember 2012).

${ }^{6}$ O'leary mengemukakan apa yang selama ini dilakukan oleh Gellner melalui tulisannya menekankan bahwa; meskipun Gellner mendirikan hubungan antara nasionalisme dan egalitarianisme di masyarakat modern, ia tidak menekankan hubungan yang saling memperkuat antara nasionalisme, egalitarianisme dan demokratisasi, apalagi, terhadap doktrin nasionalis yang bukan sesuatu yang liberal, sosialis dan konservatif, sehingga menurutnya perlu berbagi. Lihat Brendan O'leary, "On the Nature of Nationalism: An Appraisal of Ernest Gellner's Writings on Nationalism," Cambridge University Press, Great Britain B.J.Pol.S. 27, (1997),h.91.http://www. polisci.upenn.edu/ppec/PPEC\%20People/Brendan\%20O'eary/publications/Journal\%20Articles/ Oleary_BJPS_Appraisal_Gellner.pdf, (diakses pada tanggal 8 Januari 2013).

${ }^{7}$ Culla menyebutkan istilah civil society merupakan padanan kata dari "masyarakat madani". Umumnya, mereka yang menggunakan istilah "masyarakat madani" adalah yang berlatar belakang "Islam modernis", sedangkan "masyarakat sipil" atau civil society umumnya digunakan oleh mereka yang beraliran "Islam kultural". Adi Suryadi Culla, Rekonstruksi Civil Society Wacana dan Aksi Ornop 
sebuah konsep yang merujuk pada masyarakat Islam yang ada di Madinah pada masa Rasulullah Saw., yang dibangun sebagai masyarakat yang berperadaban. ${ }^{8}$ Bakti mencoba menjelaskan lebih lanjut apa yang dimaksud dengan masyarakat madani. Menurutnya kata Madinah dan Madani memiliki hubungan semantik yang erat. Kedua kata ini merujuk kepada negara. Memang, Medinat, dari akar yang sama dengan madina, juga digunakan dalam bahasa Ibrani modern, seperti pada kata Medinel Yisrael, dan memiliki konotasi agama dan hukum sebagaimana disebutkan dalam Talmud. ${ }^{9}$

Hikam, berbeda dengan Madjid, ia lebih suka menggunakan istilah civil society,dan mengemukakan bahwa civil society merupakan area yang di dalamnya terdapat kehidupan sosial yang terorganisasi dan memiliki ciri-ciri yang khas, seperti sukarela, swasembada, swadaya, dan kemandirian yang tinggi, apalagi bila berhadapan dengan negara. ${ }^{10}$ Begitu pula dengan M. Riyaas Rasyid,menurutnya civil society merupakan masyarakat yang memiliki kemandirian, tidak bergantung kepada negara dan memiliki jaringan-jaringan yang produktif. ${ }^{11}$ Berdasarkan berbagai pendapat yang muncul dari kalangan pemikir di atas inilah dapat diambil

di Indonesia, (Jakarta: LP3ES, 2006), h.35-36.

${ }^{8}$ Istilah masyarakat Madani ini pada awalnya dikenalkan oleh Anwar Ibrahim dalam Simposium Nasional dalam rangka Forum Ilmiah pada acara festival Istiqlal, 26 September 1995 di Jakarta. Pandangan ini kemudian banyak diikuti oleh cendikiawan Muslim Indonesia, seperti Nurcholis Madjid, M. Dawam Rahardjo, dan Azyumardi Azra. Lihat dalam Tim ICCE, Pendidikan Kewargaan, Demokrasi, HAM dan Masyarakat Madani, 140. Berbeda dengan Bakti yang mengemukakan bahwa sebenarnya istilah masyarakat Madani pertama kali diperkenalkan oleh Muhammad Naguib al-Attas, seorang ilmuan dari Malaysia. Anwar Ibrahim hanya melanjutkan penggunaan istilah tersebut. Andi Faisal Bakti, "On the Concept of Civil Society or Masyarakat Madani and Paramadina,h.491http://www.andifaisalbakti.com/wpcontent/ uploads/2012/04/On-the-Concept-of-Civil-Society-or-Masyarakat-Madani-and-Paramadina.pdf (diakses pada tanggal 26 Juli 2013). Konsep ini telah mengalami perluasan, sebagaimana yang dikemukakan oleh Vijender Singh bahwa konsep civil society berpindah dari 'masyarakat beradab' menuju sebuah perdebatan sosial dan memunculkan tindakan kelompok yang kini berada di luar arena politik. Vijender Singh, "An Analysis of Concept and Role of Civil Society in Contemporary," India Global Journal of Human Social Science, Volume 12 Issue 7 Version 1.0 (April 2012), 71, http://socialscienceresearch.org/index.php/GJHSS/article/view/340/298 (diakses pada tanggal 31 Desember 2012).

${ }^{9}$ Andi Faisal Bakti, "On the Concept of Civil Society or Masyarakat Madani and Paramadina,"h. 491.

${ }^{10}$ Muhammad A.S. Hikam, "Civil Society and Government Relations in the Post Reformasi Indonesia: Preliminary Observations," Usindo Brief, (19 Januari 2010), 1, http://usindo.org/wpcontent/uploads /2010/08/Hikam-Brief-Final.pdf (diakses pada tanggal 10 Januari 2013).

${ }^{11}$ Lihat dalam Sukron Kamil, Pemikiran Politik Islam Tematik,h.130. 
benang merah bahwa civil society, masyarakat madani, masyarakat sipil atau istilah lain yang dekat dengan para pemikir tersebut setidaknya memiliki ciri-ciri umum yaitu kemandirian, menempati ruang, dan berperadaban.

Definisi-definisi yang dikemukakan di atas kemudian melahirkan tipologi-tipologi civil society, yakni tipologi vertikal, tipologihorizontal (kebudayaan), dan tipologi diagonal (moderat). ${ }^{12}$ Tipologi vertikal bermakna hubungan yang berkaitan dengan politik antara civil society dengan negara, yang mana civil society berjuang untuk memperbaiki sistem politik, sehingga menjadikannya lebih demokratis. Ini merupakan sebuah konsep politik yang berkaitan secara struktural dengan negara. Salah satu tokoh pemikir yang mengungkapkan konsep civil society ini adalahAntonio Gramsci (1891-1937) yang erat dengan konsep hegemoninya. ${ }^{13}$

Gramsci menganalisis civil society dengan menggunakan konsep hegemoni. Hegomoni adalah lokus (kedudukan) dari civil society, dan ini merupakan sebuah karakteristik bagi civil society selain konflik politis dan pergulatan sosio-ekonomi. ${ }^{14}$ Meski hegemoni terkesan mengakomodir kepentingan-kepentingan ekonomi kelas penguasa, namun yang dimaksud hegemoni oleh Gramsci justru kebalikannya, menolak manifestasi langsung kepentingan ekonomi mereka dalam sebuah tatanan kehidupan masyarakat. ${ }^{15}$ Ia dengan sadar mengemukakan bahwa pembentukan sebuah

12 Tipologi vertikal juga banyak diperkenalkan oleh para peneliti lokal. Ini dilakukan untuk memudahkan penelitian dengan membedakan civil society dalam hubungannya dengan negara. Lihat Iwan Gardono Sudjatmiko, "Wacana Masyarakat Sipil di Indonesia," dalam Jurnal Sosiologi, No. 9, (Tahun 2001), 37, dalam Syamsul Hadi, dkk., "Perkembangan Wacana Civil Society," CIVIC Journal For Civil Society Empowerment vol. 1 no.3 (Desember 2003), h. 78.

${ }^{13}$ Hegemoni berarti bahwa pengaruh kepemimpinan dan intelektual kelompok atas kelompok yang lain sebagai bentuk kepemimpinan moral, bukan hanya sekedar menguasai sumber-sumber produksi. Lihat juga Peter Mayo, "The Centrality of the State in Neoliberal Times: Gramsci and beyond," International Gramsci Journal No. 3 (Maret 2011), h. 64, http://www.uow.edu.au/arts/ research/gramsci-journal/ (diakses pada tanggal 5 Maret 2013). Selain hegemoni, pemikiran politik Gramsci juga fokus pada kekuasaan dan dominasi.

${ }_{14} \mathrm{Hal}$ besar yang dilakukan oleh Gramsci adalah beradaptasi dengan Marxs dan Hegel dengan konsep Hegelian dari civil society dan gagasan dalam mengamankan negara seperti ide untuk menerima kesetaraan dialektik dengan ekonomi. Nigel Greaves, "Resisting Abstraction: Gramsci's Historiological Method," International Gramsci Journal No. 3 (Maret 2011, h. 39, http://www.uow. edu.au/arts/ research/gramsci-journal/ (diakses pada tanggal 5 Maret 2013).

${ }^{15}$ Gramsci mengembangkan analisis Marx tentang struktur dan dinamika kapitalisme namun tetap kritis terhadap pendapat yang mengagung-agungkan ekonomi kapitalis seperti Adam Smith 
hegemoni terdapat pada area civil society bukan negara. ${ }^{16}$ Negara hanyalah sebuah alat bagi suatu kelompok yang dominan untuk mengkooptasi kelompok lain dalam civil society, meski ia juga tidak menafikan bahwa antara negara dan civil society terdapat keterikatan yang membawa keduanya pada hubungan timbal-balik.

Hubungan antara civil society dengan negara setidaknya memunculkan dua argumentasi. ${ }^{17}$ Pertama, negara harus lebih kuat dari civil society agar negara dapat melakukan fungsi pengawasan terhadap civil society, tidak hanya itu, melainkan juga masyarakat secara umum. ${ }^{18}$ Pendapat kedua yang menyatakan bahwa civil society memiliki kemampuan untuk melakukan checkand balances, sehingga civil society dalam beberapa hal memiliki kemampuan yang lebih dibanding dengan negara. ${ }^{19}$ Hendro

dan lainnya. yang paling dasar dalam tingkat ekonomi-perusahaan adalah "serikat" atau "kerajinan" mentalitas dimana seorang pedagang "merasa wajib untuk berdiri dengan pedagang yang lain, produsen dengan produsen yang lain. Dengan kata lain, para anggota kelompok profesional sadar kesatuan dan homogenitas, dan kebutuhan untuk mengatur hal itu". Mike Donaldson, "Gramsci, Class and Post-Marxism," International Gramsci Journal No. 1 (Juli 2008), h. 5-18. http://www. uow.edu.au/content/groups/public/@web/@arts/@gramsci/documents/doc/uow136956.pdf (diakses pada tanggal 5 Maret 2013).

${ }^{16}$ Dalam konsep Gramscian, 'civil society' dan hubungannya dengan teori dan praktek hegemoni merupakan gagasan yang diperdebatkan. Pada banyak kasus, fokus pada hubungan antara civil society dan kekuasaan pada tingkat negara formal telah mengakibatkan abstraksi keluar dari konsep teori hegemoni secara keseluruhan. Lebih lanjut lihat dalam Kylie Smith, "Gramsci at the margins: subjectivity and subalternity in a theory of hegemony," International Gramsci Journal No.1,2 (April2010), h. 41, http://www.uow.edu.au/content/groups/public/@web/@arts/@gramsci/ documents/doc/uow134747.pdf (diakses pada tanggal 3 Maret 2013).

17 Yaman dalam tesisnya mengungkapkan bahwa gagasan mengenai civil society telah lama muncul sejak abad ke-18, yang mana ide awal mengenai gagasan ini mencuat karena hubungannya dengan negara. Awal mula abad ke-18, ia mengungkapkan bahwa civil society dilambangkan sebagai antitesis terhadap negara. Kemudian berkembang lagi pada abad ke19 yang mengkombinasikan civil society dengan masyarakat borjuis, ekonomi dan pasar. Baru pada abad ke-20, civil society memiliki makna khusus yang berkaitan dengan demokrasi. Lihat Mine Yaman, "Civil Society and Democratic Consolidation: the Case of Tusiad," (Tesis Bilkent University: Ankara, 2002), 3, http://www.thesis.bilkent.edu.tr/0002069.pdf (diakses pada tanggal 16 Januari 2013).

${ }^{18}$ Ini adalah sebuah konsep yang sering diungkapkan oleh Hegel dan para pengikut setianya. Mereka berpendapat bahwa negara adalah perwujudan tertinggi dari nilai Ilahi di muka bumi. Negara memiliki kekuasaan absolut dalam memanifestasikan dirinya sebagai ungkapan menuju pemenuhan kebutuhan yang sempurna bagi warganya. Edward W. Younkins, "Hegel's Authoritariant State as the Divine Idea on Earth," Le Quebecois Libre, Montreal (15 November 2005), http://www.quebecoislibre.org/05/051115-11.htm (diakses pada tanggal 16 Januari 2013).

${ }^{19}$ Islamoglu mengemukakan pendapat yang sering disampaikan oleh para filosof Yunani bahwa baik privasi dan civil society perlu dipertahankan terhadap gangguan-gangguan yang 
Prasetyo serta Ali Munhanif berpandangan bahwa dalam hal ini civil society merupakan sebuah tameng yang menjadi pelindung bagi masyarakat dalam berhubungan dialektis dengan negara. ${ }^{20}$

Tipologicivil society kedua adalah tipologi horizontal, yakni civil society hubungannya dengan budaya yang memiliki sifat yang khas, seperti religius, kesukuan, membela kepentingan umum dan hak-hak kolektif, memiliki kepercayaan, keyakinan, serta simbol dan nilai-nilai. ${ }^{21}$ Konsep kebudayaan yang dikemukakan oleh beberapa kalangan seperti Koentjaraningrat dan Sukron Kamil akan membantu dalam memahami maksud dari civil society budaya. Menurut Koentjaraningrat kebudayaan merupakan wujud ideal yang bersifat abstrak dan tak dapat diraba yang ada dalam pikiran manusia, dapat berupa gagasan, ide, norma, keyakinan, dan lainnya. ${ }^{22}$ Kamil menyebutkan pendapat Clyde Kluckhon bahwa kebudayaan merupakan sistem ide, pengetahuan, dan acuan bagi manusia untuk menjalani kehidupan. Sedangkan Kamil mendefenisikan kebudayaan adalah cara berpikir, cara merasa, cara meyakini, dan cara menganggap. ${ }^{23}$ Definisi kebudayaan inilah kemudian yang mendasari lahirnya civil society budaya.

Civil society dalam tipologi ini berawal dari apa yang dikemukakan oleh Alexis de' Tocqueville berpendapat bahwa meskipun antara civil society dan negara terdapat hubungan timbal balik, layaknya sebuah hubungan simbiosis mutualisme, namun nilai dari civil society itu sendiri baru bisa

\footnotetext{
dilakukan oleh negara. Lihat H. Islamoglu, "Civil Society/Public Sphere: History of the Concept," International Encyclopedia of the Social \& Behavioral Sciences: Elsevier Science, 2001, 1897, http:// www.nyu.edu/ipk/calhoun/files/calhounCivilSocietyPublicSphereHistoryOfConcept.pdf, (diakses pada tanggal 22 Januari 2013).

${ }^{20}$ Sukron Kamil, Pemikiran Politik Islam Tematik, h. 133.

${ }^{21}$ Baca juga Iwan Ismi Febriyanto, "Konsep dan Tipologi Civil Society dalam Negara Demokrasi," dalam http://sosialitadanpolitik.blogspot.com/2012/10/konsep-dan-tipologi civilsociety-dalam.html (diakses pada tanggal 27 Juli 2013).

22 "Pengertian Budaya," 16, http://thesis.binus.ac.id/doc/Bab2/2006-2-00920-JP-bab\%202. pdf (diakses pada tanggal 27 Juli 2013). Dalam referensi lain disebutkan bahwa kebudayaan menurut Koentjaraningrat adalah keseluruhan gagasan dan karya manusia, yang harus dibiasakannya dengan belajar, beserta keseluruhan dari hasil budi dan karyanya itu. Encep Supriatna, "Transformasi Pembelajaran Sejarah Berbasis Religi dan Budaya untuk Menumbuhkan Karakter Siswa," 25, http:// atikan-jurnal.com/wp-content/uploads /2012/06/2.encep_.upi_.jun_.12.pdf (diakses pada tanggal 27 Juli 2013).

${ }^{23}$ Lihat Sukron Kamil, "Korupsi sebagai Persoalan Kebudayaan: Mencari Akar Masalah Korupsi di Indonesia dan Solusinya," dalam Korupsi mengorupsi Indonesia: sebab, akibat, dan prospek pemberantasan, edt. Wijayanto dan Ridwan Zachrie (Jakarta: PT Gramedia Pustaka Utama, 2009), h. 46.
} 
dibangun dan dikembangkan ketika dihadapkan pada negara. ${ }^{24}$ Lebih jauh, berdasarkan penelitian de' Tocqueville inilah muncul ciri-ciri yang kini popular dengan ciri-ciri civil society kebudayaan (horizontal). Kamil menyebutkan setidaknya tipologi tersebut memiliki dua ciri utama, yaitu civility (keberadaban) dan fraternity (persaudaraan), sedangkan ciri pendukungnya adalah trust (kepercayaan), solidaritas, toleransi, akuntabilitas, kerterikatan pada hukum, dan menjunjung tinggi hak asasi manusia (HAM). ${ }^{25}$ Masyarakat yang memiliki ciri seperti ini oleh Nurcholis Madjid disebut dapat menjadi civil society yang sesungguhnya, yakni yang berperadaban.

Dawam Rahardjo dan AS. Hikam, mengemukakan tipologi ini berupa ruang (space) antara rakyat dengan negara. Mereka berpendapat dalam beberapa hal bersifat strategis dan demi kepentingan bersama civil society akan menjadi mitra bagi negara, sebaliknya, dalam persoalanpersoalan yang tidak strategis civil society justru akan menjadi alternatif dari pemerintah itu sendiri. ${ }^{26}$ Civil society memiliki peran yang lebih tidak hanya melakukan critical of government, lebih dari itu, mejadi alternatif dari pemerintah ketika persoalan dalam sebuah negara sudah semakin parah. ${ }^{27}$ Oleh sebab itu, civil society dalam hal ini memiliki ciri kesukarelaan (voluntary), keswasembadaan (self generating), keswadayaan (self supporting), kemandirian terhadap negara, dan terikat pada peraturan bersama.

Tipologi civil society terakhir adalah tipologi moderat yang meng-

${ }^{24}$ Hubungan dialektis akan semakin memperlihatkan peran civil society. Setidaknya ada tiga hal yang dapat menjadikan hubungan tersebut dialektis, yaitu mendukung negara, menjadi antitesis dari negara, atau menjadi alternatif dari negara ketika negara tidak mampu untuk menjalankan perannya sebagai pemberi kemaslahatan bagi warganya.

${ }^{25}$ Sukron Kamil, Pemikiran Politik Islam Tematik, 130.

${ }^{26}$ Hikam menjelaskan bahwa sebenarnya negara adalah hasil karya dari masyarakat, bukan sebaliknya. Pembagian peran dan fungsi baru terjadi ketika masyarakat sudah semakin modern, sehingga semakin jelas bahwa masyarakat sambil mencoba mengontrol apa yang terjadi di wilayah negara. Muhammad A.S. Hikam, Islam, Demokratisasi, dan Pemberdayaan Civil Society (Jakarta: Erlangga, 2000), h. 82.

${ }^{27}$ Sulistyo menyebutkan bahwa negara berkewajiban secara kolektif memberikan rasa aman terhadap warga negaranya, dan secara kolektif pula meningkatkan kesejahteraan dan kualitas hidup seluruh masyarakat. Dermawan Sulistyo, dkk., Keamanan Negara, Keamanan Nasional dan Civil Society (Jakarta: Pensil, 2009), h. 199. Pendapat ini seakan memberikan isyarat bahwa ketika negara sudah tidak lagi mampu menangani persoalan yang kian berat yang terjadi pada rakyatnya, maka civil society muncul sebagai alternatif. 
gabungkan dua tipologi sebelumnya. Tipologi ini berupa civil society yang mandiri, yang menempati ruang, kritis, dan mengedepankan kemaslahatan umum. Ia merupakan sebuah lembaga non pemerintah yang memiliki kemampuan untuk melakukan hubungan timbal-balik yang saling menguntungkan dengan pemerintah, karena civil society memiliki kemampuan untuk mendukung negara. Tipologi ini lebih dikenal dengan istilah pilar-pilar penegak civil society yang terdiri dari organisasiorganisasi civil society,mahasiswa, dan media massa. ${ }^{28}$ Organisasi-organisasi tersebut seperti organisasi politik, organisasi kemasyarakatan, lembaga pendidikan, lembaga swadaya masyarakat dan organisasi pemberdayaan perempuan. ${ }^{29}$ Pilar-pilar ini memiliki fungsi mendukung dan mengawasi, bahkan terkadang berfungsi pula sebagai alternatif.

Para cendikiawan Muslim memiliki pandangan yang berbeda dengan para pemikir di atas.Bakti mengemukakan terdapat pemikir Islam yang berbicara tentang civil society, salah satunya adalah Ibnu Khaldun yang mengemukakan konsep hadhârah yang dapat diterjemahkan sebagai peradaban. Kata ini berasal dari kata "sipil" dalam masyarakat sipil. ${ }^{30}$ Pemikir lainnya tidak secara gamblang menyebut istilah civil society, akan tetapi mengisyaratkannya melalui kriteria dalam pengangkatan seorang pemimpin.

Beberapa pemikir yang berbicara mengenai kriteria dalam mengangkatan seorang pemimpin adalah al-Mawardi, al-Baqillani dan Abu Ya'la al-Farra. Al-Mawardi memberikan 12 kewajiban dasar yang harus dilakukan oleh seorang pemimpin. ${ }^{31}$ Ketika kedua belas kewajiban dasar tersebut sudah tidak lagi dapat dilakukan oleh seorang pemimpin, maka pemimpin tersebut harus dilengserkan. Al-Baqillani berpendapat bahwa seorang pemimpin yang meninggalkan salat, tidak menegakkan syariat,

${ }^{28}$ Tim ICCE, Pendidikan Kewargaan, Demokrasi, HAM dan Masyarakat Madani, h 141.

${ }^{29}$ Lihat juga Sukron Kamil, Pemikiran Politik Islam Tematik, h.131-132.

${ }^{30}$ Andi Faisal Bakti, "On the Concept of Civil Society or MasyarakatMadani and Paramadina, h 489.

${ }^{31}$ Martinez mengemukakan pendapat al-Mawardi bahwa ada dua belas kewajiban dasar yang harus dimiki oleh seorang pemimpin, salah satunya adalah meletakkan sistem yudisial untuk menyelesaikan konflik dan keadilan. Patricia A Martinez, "The Islamic state or the state of Islam in Malaysia," Contemporary Southeast Asia; (Desember 2001), 492, dalamhttp://e-resources.pnri. go.id:2058/docview/205217493/ fulltextPDF/13D0561442C4A69581E/3?accountid=25704 (diakses pada tanggal 25 Maret 2013). Bila kewajiban-kewajiban ini tidak dapat dipenuhi maka pemimpin itu layak untuk mundur atau dilengserkan. 
melakukan pelanggaran terhadap hak-hak dasar masyarakat, seperti berbuat zalim dan membunuh, maka ia harus diberhentikan dari jabatannya sebagai pemimpin. Sedangkan Abu Ya'la al-Farra, lebih sensitif dari al-Mawardi dan al-Baqillani yang mengemukakan bahwa bila seorang pemimpin memiliki kekurangan pada dirinya dan berpengaruh terhadap roda pemerintahan yang dipimpinnya dan hal itu sulit untuk diobati, maka ia wajib memecat dirinya sendiri. ${ }^{32}$

Kamil menyebutkan bahwa berbagai kriteria yang disampaikan oleh para pemimpin di atas agaknya oleh para pemikir dikembalikan pada dua konsep pemilihan yaitu abl al-Halli wa al-Aqd atau abl asSyaukah (seperti lembaga perwakilan rakyat), bisa juga dengan bai'at. Sedangkan pelengseran dilakukan dengan cara-cara yang tidak sah, seperti mengangkat senjata, fitnah (kekacauan atau anarki) dan ikhtilâf (perbedaan pandangan). ${ }^{33}$ Pelengseran yang dilakukan merupakan sebuah bentuk perlawanan terhadap pemerintahan guna memperoleh kekuasaan, namun dalam konsep civil society perlawanan dilakukan bukan sekedar ingin menggulingkan kekuasaan, melainkan mendukung kekuasaan yang sedang berjalan. Hal ini disebabkan pemerintah dianggap belum mampu untuk memenuhi semua kebutuhan rakyatnya, sehingga membutuhkan dukungan dari civil society. Inilah yang oleh Masoud Kamali disebut sebagai sebuah hal yang diinginkan oleh Islam dan sistem pemerintahan modern. ${ }^{34}$ Negara memberikan ruang bagi civil society untuk melakukan tindakan yang mampu mendukung negara dalam mengatasi persoalan warganya.

${ }^{32}$ Sukron Kamil, Pemikiran Politik Islam Tematik, h .147.

${ }^{33}$ Sukron Kamil, Pemikiran Politik Islam Tematik, 148. Abl al-Halli wa al-Aqd secara harfiah berarti orang yang dapat memutuskan dan mengikat. Sedangkan para ahli fiqh siyasah mengartikan ini sebagai orang yang memiliki kewenangan untuk memutusan dan menentukan sesuatu atas nama umat (warga negara). Lebih lanjut lihat dalam Muhammad Iqbal, Figh Siyasah: Kontekstualisasi Doktrin Politik Islam (Jakarta: Gaya Media Pratama, 2007), h.137.

${ }^{34}$ Masoud Kamali mengemukakan bahwa civil society yang ada di negara-negara Muslim dibangun atas kelompok tradisional seperti ulama dan pedagang melalui perubahan-perubahan utama, kemudian mengalami proses modernisasi seperti yang ada pada masyarakat. Masoud Kamali, "Civil Society and Islam: a Sociological Perspective," Archives Européennes de Sociologie 42. 3 (Desember 2001), 479, http://eresources.pnri.go.id:2058/docview/216940878/fulltextPD F/13D096BA4AD2C1F726D/1 ?accountid=25704 (diakses pada tanggal 4 Maret 2013). Inilah yang tidak dipahami oleh kebanyakan pemikir barat dikarenakan kegagalan mereka dalam memahami Islam sebagai agama dan juga teori politik yang menjadikannya sebagai sumber pengesahan kekuasaan. 
Al-Farabi memberikan pandangan khusus dalam hal ini. Menurutnya negara seperti organ tubuh manusia. Otak atau akal adalah pimpinan utama dalam mengendalikan sistem koordinasi tubuh. Organ-organ tubuh yang lain akan bersinergi dengan akal untuk melakukan apa yang dikehendaki. Ini berarti bahwa masyarakat adalah ujung tombak atau pelaku utama dalam sebuah negara, sedangkan kepala negara merupakan pembuat sistem yang akan dijalankan oleh rakyatnya, meski terkadang rakyat harus sedikit bertoleransi pada aturan yang memberatkan mereka. ${ }^{35}$ Civil society dalam hal ini berperan sebagai sebuah sarana yang memediasi negara dengan warganya.

Sama halnya dengan al-Mawardi bahwa masyarakat yang baik adalah masyarakat yang taat peraturan. Ibn Thaimiyah menambahkan, masyarakat juga dapat berperan dalam memberikan analisis tajam terhadap pemerintah. Lebih jauh menurut Kamil, Ibn Thaimiyah menekankan bahwa prinsip dasar yang ditekankan dalam Al-Quran pada sistem pemerintahan adalah amanah dan adil. Ketika dua hal ini tidak lagi dapat dijalankan dengan baik oleh seorang pemimpin, maka rakyat berkewajiban untuk melakukan kritik terhadap pemerintahan tersebut. ${ }^{36}$

Penjelasan mengenai sikap para pemikir Islam di atas, jika dikelompokkan berdasarkan pada tiga tipologi civil society, maka baik alMawardi, al-Baqillani, Abu Ya'la al-Farra, al-Farabi, dan Ibn Thaimiyah agaknya berpendapat bahwa hubungan civil society lebih bersifat struktural daripada kebudayaan apalagi organisasi-organisasi civil society. Padahal konsep Islam dan civil society oleh banyak kalangan juga dilihat dari sisi kebudayaan dan organisasinya.

Hubungan kebudayaan dan organisasi-organisasi civil society ini

${ }^{35}$ Menurut Al-Farabi, pertanyaan dari toleransi sama seperti pertanyaan politik secara umum, yakni memusatkan perbedaan alami antara manusia dalam kemampuan mereka untuk memahami esensi apa yang dimaksud. Ini menjadi sebuah hal yang prinsip, dengan meningkatkan kesejahternaan masyarakat dan peraturan yang mudah dicermati serta dilaksanakan oleh semua orang. Al-Farabi, The Political Regime, trans. Muhsin Madhi, dalam Medieval Political Philosophy, ed. Ralph Lerner and Muhsin Madhi (Ithaca: Cornell University Press, 1993), 40, dalam Michael Sweeney, "Greek Essence and Islamic Tolerance: Al-Farabi, Al-Ghazali, Ibn Rush'," The Review of Metaphysics 65. 1 (September 2011), 41, http://e-resources.pnri.go.id: 2058/ docview/897114386/ fulltextPDF/13D09A4757 A72532390/3?accountid=25704 (diakses pada tanggal 26 Maret 2013). Lihat juga Sukron Kamil, Pemikiran Politik Islam Tematik, h 151.

${ }^{36}$ Lihat Sukron Kamil, Pemikiran Politik Islam Tematik, h.152. 
dapat dilihat dari konsep ummah. ${ }^{37}$ Konsep ini berawal dari sebuah sistem transregional perdagangan Muslim dan jaringan haji. Jaringan ini dihubungkan oleh perkembangan informasi dan teknologi yang mana telah menyediakan ruang kesempatan untuk pergerakan sosial Muslim guna memobilisasi melalui sebuah kebangkitan ummah sebagai sebuah ajaran Islam universal. ${ }^{38}$ Konsep inilah yang dianggap dapat menyatukan umat Muslim secara global dan menjalankan sebuah pergerakan pada lebih dari dua negara, ${ }^{39}$ berdasarkan kesamaan agama, yakni Islam.

Konsep ummah lebih luas dari pengertian civil society secara vertikal yang bertujuan untuk memperbaiki dan mengembalikan nilai-nilai sosial yang selama ini tidak terfokus, bahkan tidak diperhatikan oleh pemegang kekuasaan..$^{40}$ Lebih dari itu, ummah muncul sebagai sebuah ajaran normatif salah satunya bertujuan untuk mengatasi kemunduran dan krisis pada umat yang mengakibatkan timbulnya solidaritas dan menetapkannya sebagai pergerakan. ${ }^{41}$ Pada tataran praktis Joshua D.

${ }^{37}$ Konsep ummah berbeda dengan konsep civil society yang dikenalkan oleh Barat. Dalam konsep ini terdapat nuansa keagamaan, ukhwah, transendental, dan berperadaban yang religius dibanding civil society yang sekuler dan berpotensi pada disintegrasi umat. Lihat juga Adi Suryadi Culla, Masyarakat Madani: Pemikiran, Teori dan Relevansinya denganCita-cita Reformasi (Jakarta: Raja Grafindo Persada, 1999), cet. II, 111-113., Iqbal mengemukakan bahwa ummah bersifat universal meliputi seluruh kaum Muslim, dan disatukan oleh ikatan ideologi yang kuat dan komprehensif, yaitu Islam. Muhammad Iqbal, Fiqh Siyasah, 178.

${ }^{38}$ Joshua D. Hendrick, "Global Islam and the Modern World: Transnational Muslim Social Movements and the Movement of Fethullah Gülen, a Comparative Approach," dalamIslam in the Contemporary World-2 (New Jersey: Tughra Books, 2009), h. 124.

${ }^{39}$ Pergerakan sosial keagamaan kini tidak hanya menjadi pergerakan transregional, melainkan sudah meluas menjadi pergerakan transnasional. Lihat Jackie Smith, Charles Chatfield, and Ron Pagnucco, edt. Transnational Social Movements and Global Politics, (New York: Syracus University Press, 1997), h.43.

40 Bill Moyer, "The Movement Action Plan: A Strategic Framework Describing The Eight Stages of Successful Social Movements," http://historyisaweapon.com/defcon1/moyermap. html, (diakses pada tanggal 07 Mei 2012). Konsep ummah juga tidak dapat disamakan dengan konsep civil society secara umum, seperti konsep Hegelian atau Marxis. Para pengikut Hegel memaknai civil society sebagai sesuatu yang dapat melumpuhkan diri sendiri, sedangkan pengikut Marx menganggap civil society adalah sebuah penghambat menuju masyarakat tanpa kelas.

${ }^{41}$ Ini juga terjadi pada pergerakan Muhammadiyah, yang mana gagasan utama yang melahirkan pergerakan sosial keagamaan karena pemahaman terhadap sumber (kitab), ulama, praktek ajaran Islam dan fakta kehidupan umat yang menimbulkan keprihatinan. Gagasan ini yang mendorong Ahmad Dahlan membentuk Muhammadiyah. Lihat lebih lanjut dalam Syarifuddin Juhri dkk, 1 Abad Muhammadiyah Gagasan Pembaruan Sosial Keagamaan (Jakarta: Kompas, 2010), h. 15. 
Hendrick menyebutkan pernyataan Samuel Huntington dalam outline tesisnya "Clash of Civilization" yang sepakat bahwa menguatnya konsep ummah diwujudkan melalui pergerakan sosial Muslim. Ini disebabkan adanya sebuah indikasi dari perpecahan budaya antara Barat dan Isla.

\section{Pergerakan Hizmet sebagai Civil Society Transnasional Muslim yang Diinspirasi oleh Fethullah Gülen}

Pergerakan hizmet merupakan salah satu pergerakan civil society transnasional yang fokus terhadap kemunduran umat Muslim. Hizmet adalah kata dalam bahasa Turki, dalam bahasa Arab disebut khidmah, yang berarti pelayanan, ${ }^{42}$ sedangkan secara terminologi hizmet merupakan ideologi penyadaran sosial yang bertujuan untuk menghamba kepada Allah Swt. dan diwujudkan melalui pengabdian serta pelayanan kepada sesama guna mendapatkan ridhâ-Nya. Istilah ini berkontribusi secara luas dan berpartisipasi dalam kehidupan sosial-ekonomi, tidak hanya dalam konteks Muslim tetapi juga dalam konteks non-Muslim. ${ }^{43}$ Ini kemudian menjadi sebuah ideologi yang dianut oleh berbagai kalangan dengan berbagai pofesi dan menjadikannya sebagai sebuah pergerakan yang dikenal dengan pergerakan hizmet.

Pergerakan hizmet diinspirasi oleh Muhammad Fethullah Gülen, tokoh sentral yang memberikan pengaruh besar dalam penyebaran ideologi pergerakan hizmet di berbagai negara. Ia adalah sosok yang melanjutkan apa yang dilakukan oleh Said Nursi melalui institusionalisasi pendidikan, ekonomi, dan resolusi konflik melalui dialog. ${ }^{44} \mathrm{Hal}$ ini

\footnotetext{
${ }^{42}$ Ahmad Sunarto, Kamus Alfikr (Surabaya: Halim Jaya, 2007), cet. III.

43 Erkan Togoslu, "Hizmet: from Futuwwa Tradition to the Emergence of Movement in Public Space," (15 November 2008), Fethullah Gülen Chair, dalam www.fethullahGülenchair. com(diakses tanggal 9 November 2011). Lebih lanjut Enayat mengatakan bahwa pembatasan yang ditempatkan oleh syarîah dalam kebenaran non-muslim tidak permanen dan tidak dapat dihilangkan karena non-muslim selalu memiliki pemikiran untuk masuk ke dalam agama Islam, dan dengan cara demikian mereka mengatasi ketidakmampuan politik. Hamid Enayat, Modern Islamic Political Thought (Kuala Lumpur: The Macmillan Press, 2001), h. 189.

${ }^{44}$ Pria kelahiran Desa Erzurum, Izmir, Turki, pada tanggal 27 April 1941, merupakan seorang pemikir yang sangat populer tidak hanya di negaranya, tetapi juga telah meluas ke negara-negara lain. Gerakan dialog mencapai puncaknya pada sebuah konferensi yang dilakukan di Vatikan, Roma. Gülen bertemu dengan Paus Johanes Paulus II atas undangan pimpinan tertinggi gereja katolik tersebut. Muhammad Fethullah Gülen, Bangkitnya Spiritualitas Islam, terj. Fuad Saefuddin(Jakarta: Republika, 2013), XVIII.
} 
diajarkan melalui jaringan transnasional dershane, ${ }^{45}$ seperti apa yang telah dilakukan oleh Nursi sebelumnya. Ia juga memberikan pandangan yang tidak bertentangan dengan prinsip-prinsip demokrasi, seperti pandangannya terhadap kompleksitas kehidupan modern, kontraksi dalam keterbukaan ruang individu dan ekspresi kolektif budaya, moral dan nilai-nilai spiritual. ${ }^{46}$

Pemikiran Gülen memang banyak dipengaruhi oleh gurunya Said Nursi (1876-1960), ${ }^{47}$. Seorang ulama yang berpandangan Islam SunniHanaf, ${ }^{48}$ dan hidup sezaman dengan tokoh sentral pencetus sekularisasi Turki, Mustafa Kemal Attaturk. Nursi banyak menghasilkan karya berupa kitab-kitab yang dikenal dengan Risale-i Nur. Karya-karya inilah yang menginspirasi Gülen untuk mengajarkan dan mengaplikasikan pesanpesan Risale-i Nur dalam konteks global. ${ }^{49}$ Gülen dan pengikutnya

${ }^{45}$ Desrshane berasal dari kata ders yang berarti pelajaran dan hane yang berarti rumah. Secara etimologi kata dershane berarti rumah belajar, sedangkan secara terminologi dershane berarti sebuah tempat untuk menginternalisasi teks-teks filosofis risalei nur. Yavuz menyebutkan bahwa Gülen telah membentuk jaringan transnasional dershane yang kuat. Lihat dalam M. Hakan Yavuz, "Nasil bir Thrkiye" (What Type of Turkey?), Milliyet (Istanbul), (11 August 1997), dalam M. Hakan Yavuz, "Towards an Islamic Liberalism?," 593. Bandingkan dengan Çetin yang menyebutkan bahwa Gülen menginspirasikan sebuah pergerakan sosial sipil transnasional yang terdapat di Turki sebagai sebuah dasar keimanan inisiatif budaya — bukan membentuk jaringan transnasional. Lihat dalam Muhammed Çetin, "The Contribution of Islamic Scholarship to Democracy," 105. disampaikan pada konferensi The Significance of Education for the Future: The Gülen Model of Education, UIN Syarif Hidayatullah Jakarta, Jakarta-Indonesia, 19-21 Oktober 2010.

${ }^{46}$ Muhammed Çetin, "The Contribution of Islamic Scholarship to Democracy", 103.

${ }^{47}$ Said Nursi adalah pemikir Islam yang melahirkan karya fenomenal yang dikenal dengan Risale-i Nur. Lebih lanjut lihat dalam Sükran Vahide, Biografi Intelektual Bediuzzaman Said Nursi: Transformasi Dinasti Utsmani Menjadi Republik Turki (Jakarta: Anatolia,2007). Pemikiran Nursi sendiri banyak dipengaruholeh tokoh sufi terkenal yaitu Maulana Jalaluddin Rumi. Sebelum Nursi, juga ada pemikir lain yang juga mempengaruhi pemikiran Gülen, yaitu Muhammad Lutfi yang berasal dari Alvar. Gülen mengistilahkan apa yang dikemukakan oleh Lutfi adalah seperti ilham yang datang dari alam lain. Muhammad Fethullah Gülen, Bangkitnya Spiritualitas Islam, XI.

${ }^{48}$ Bruckmayr mengemukakan bahwa Gülen serta misi pergerakannya dipengaruhi oleh pemikiran Nursi yang menekankan keprihatinan mereka terhadap dialog antar umat beragama. Philipp Bruckmayr, "Fethullah Gülen and Islamic Literary Tradition", Islam in the Age of Global Challenges-Conference Proceedings, 17 November 2008, 168, http://medya.zaman.com.tr/2008/11/17/ bruckmayr.pdf (diakses pada tanggal 20 Maret 2013).

${ }^{49}$ Apa yang dilakukan oleh Said Nursi kemudian diteruskan oleh Fethullah Gülen dan pengikutnya. Ini telah dilakukan lebih dari satu abad. Pergerakan ini bertujuan untuk mentransformasikan hubungan pemikiran politik imperatif dari masyarakat modern. Karen A. Fontenot dan Michael J. Fontenot, "M. Fethullah Gülen as a Transformational Leader: Exemplar for the "Golden Generation", h. 2. 
kemudian terlibat dalam pergerakan nurcu dan mempopulerkan pergerakan hizmet yang memfokuskan pergerakan pada bidang pendidikan, dialog sertaekonomi. ${ }^{50}$ Gülen sepertinya memahami benar apa yang dikemukakan oleh Al-Mawardi mengenai kriteriau ntuk menjadi seorang pemimpin diantaranya harus berpengetahuan dan visioner. ${ }^{51}$ Oleh sebab itu, ketiga bidang yang menjadi fokus pergerakan hizmet merupakan wujud dari sebuah visi yang jelas demi mengatasi kemunduran tidak hanya umat Muslim, tetapi juga masyarakat luas.

Pemikiran Gülen yang moderat memunculkan berbagai spekulasi, bahwa di satu sisi, pergerakan hizmet adalah pergerakan yang liberal karena tidak ekslusif bagi umat Muslim semata, sedangkan di sisi lain, pemikiran-pemikirannya dianggap dapat menjadi penyeimbang bagi para pemikir Islam yang ekstrem dan fundamental..$^{52}$ Dua sisi argumentasi ini bila melihat definisi civil society yang dikemukakan oleh AS Hikam, maka pergerakan hizmet memiliki ciri yang khas, yaitu tidak memihak pada pihak manapun dan memiliki kemandirian, bahkan terhadap negara sekalipun. ${ }^{53}$

Bentuk kemoderatan Gülen diwujudkan melalui dialog. Kim men-

${ }^{50}$ Pergerakan yang dibuat oleh Gülen lebih didedikasikan kepada pendidikan, sebuah pendidikan dari hati dan jiwa, bertujuan untuk memperkuat kemampuan dan menyediakan kebaikan serta melayani orang lain dengan sepenuhnya. Muhammad Fethullah Gülen, EssayPerspektives-Opinions, h.9.

${ }^{51}$ Lihat juga Patricia A Martinez, "The Islamic State or the State of Islam in Malaysia," Contemporary Southeast Asia; (December 2001), h. 492,http://eresources.pnri.go.id:2058/ docview/205217493/fulltextPDF/13D0561442C4A69581E/3?accountid=25704 (diakses pada tanggal 25 Maret 2013).

52 James Harrington, seorang pakar Hak Sipil Universitas Texas, membuat sebuah buku yang berjudul "Penguatan kebebasan berpendapat, Beragama dan Demokrasi di Turki: Pengadilan Politik Fethullah Gülen". Ia mengatakan bahwa gerakan Gülen merupakan gerakan yang paling baik dalam memerankan demokratisasi di Turki saat ini. Gerakan ini telah memainkan peranan yang lebih luas dalam lingkup global. Selain membantu merubah citra buruk yang selama ini melekat pada Islam. Red. Yudha Manggala P Putra, "Pakar Barat: Turki Contoh Ideal bagi Dunia Islam", Republika Online, http://www.republika.co.id/berita/dunia-islam/islammancanegara/12/05/02/m3e7yp-pakar-barat-turki-contoh-ideal-bagi-dunia-islam (diakses pada tanggal 11 Nopember 2012).

${ }^{53}$ Hikam mengemukakan bahwa civil society merupakan area yang di dalamnya terdapat kehidupan sosial yang terorganisasi dan memiliki ciri-ciri yang khas, seperti sukarela, swasembada, swadaya, dan kemandirian yang tinggi, apalagi bila berhadapan dengan negara. Lihat dalam Muhammad A.S. Hikam, "Civil Society and Government Relations in the Post Reformasi Indonesia: Preliminary Observations," Usindo Brief, (19 Januari 2010), h. 1, http://usindo.org/ wp-content/ uploads/2010/08/Hikam-Brief-Final.pdf (diakses pada tanggal 10 Januari 2013). 
jelaskan bahwa menurut Gülen, dialog muncul sebagai konsekuensi alami dari humanisme, dan ia mendefinisikan humanisme sebagai doktrin cinta dan kemanusiaan. Dialog dalam arti sebenarnya adalah sublimasi dan perpanjangan pragmatis humanisme, yang hanya dapat dilakukan dengan saling menghormati, toleransi dan cinta. ${ }^{54}$

Ide ini berkembang tidak hanya dialog secara individu, tetapi juga melalui lembaga, guna mencapai sebuah kesepahaman antara satu dengan yang lain. John Locke dalam teori kontrak sosial juga mengemukakan demikian. Menurut Locke, civil society adalah hasil dari kontrak sosial dari masyarakat yang telah disepakati bersama. ${ }^{55}$ Sama halnya dengan kesepakatan yang dilakukan oleh para tokoh yang berperan aktif dalam dialog, meski dialog yang dilakukan melibatkan berbagai kalangan akan tetapi tujuannya adalah mencapai kesepahaman agar tercapainya kehidupan umat beragama yang rukun dan harmonis, serta demi kepentingan bersama.

Ajaran Gülen tentang dialog merupakan sebuah alternatif yang diperuntukkan bagi dua gerakan yang selama ini mengatasnamakan jihad atau pergerakan fundamentalis dan orang-orang di Barat yang meyakini adanya benturan peradaban antar penganut agama. ${ }^{56}$ Meski Barat saat ini menjadi kiblat bagi kemodernan, namun Bilici mengemukakan dalam kesimpulannya bahwa pergerakan hizmet yang diinspirasi oleh Gülen melakukan sebuah upaya modernisasi tanpa westernisasi, yaitu berusaha untuk menciptakan modernitas non-Barat. ${ }^{57}$ Ini dianggap menjadi sebuah ketidakberpihakan Barat dan memiliki ciri khas tersendiri tanpa mengatasnamakan kelompok manapun, seperti kelompok yang mengatasnamakan jihad tersebut.

Wujud lain yang ditunjukan sebagai bentuk kemoderatan Gülen dan pergerakan hizmet adalah toleransi. Toleransi merupakan wujud dari cinta yang diajarkan oleh Gülen dan kemudian mempertimbangkannya

${ }^{54}$ Heon C. Kim dalam Editorial, "Fethullah Gülen, The Most Important Figure of Tolerance and Dialogue," 4.http://en.fgulen.com/press-room/news/3620-fethullah-gulen-the-most-importantfigure-of-tolerance-and-dialogue-says-dr-heon-kim?format=pdf (diakses pada tanggal 20 Maret 2013).

${ }_{55}$ Baca juga Eric R. Claeys, "The Private Society and the Liberal Public Good in John Locke's Thought," 231 dan 234, (diakses pada tanggal 6 Maret 2013).

${ }^{56}$ Editorial, "Fethullah Gülen, The Most Important Figure of Tolerance and Dialogue", h.1.

${ }^{57}$ Mucahit Bilici, "The Fethullah Gülen Movement and Its Politics of Representation in Turkey," The Muslim World 96. 1 (Januari 2006), 17,http://eresources.pnri.go.id:2058/ docview/216435705/fulltextPD/ 13D1ECA416C18E38ADF/1 ?accountid=25704 (diakses pada tanggal 30 Maret 2013). 
sebagai model dari dialog antar agama, budaya dan peradaban. ${ }^{58}$ Ini menjadi sebuah hal yang menarik karena melibatkan tidak hanya kalangan pergerakan hizmet itu sendiri, melainkan juga di luar dari pergerakan tersebut. Dawam Rahardjo dan AS. Hikam dalam tipologi civil society kebudayaan mengemukakan hal ini memang wajar terjadi. Civil society akan secara sukarela melakukan berbagai hal yang dianggap perlu untuk dilakukan. Oleh sebab itu, selain kesukarelaan ciri lain yang dimilikinya adalah keswasembadaan dan keswadayaan, mandiri serta terikat pada peraturan bersama..$^{59}$ Ini membuktikan secara sederhana bahwa pergerakan hizmet masuk dalam kategori pergerakan civil society yang berbasis budaya, maka ia tergolong pada tipologi kebudayaan.

Alexis de' Tocqueville menyebutkan bahwa civil society dengan tipologi kebudayaandidasarkan pada trust (kepercayaan) dan solidaritas. ${ }^{60}$ Para pelaku pergerakan hizmet percaya dengan apa yang dikomunikasikan oleh Gülensecara langsung maupun melalui buku atau media lain, sehingga pergerakan ini menjadi solid dengan kesatuan ideologi yang dianutnya. Hal ini senada dengan apa yang dikemukakan oleh M. Riyas Rasyid bahwa civil society memiliki jaringan-jaringan yang produktif. ${ }^{61}$ Jaringanjaringan produktif inilah yang dikenal dengan jaringan formal dan informal. Jaringan produktif tersebut tidak hanya yang menghasilkan pendapatan ekonomi, lebih dari itu, dapat menanamkan ideologi hizmet dan menerapkannya dalam berbagai hal. Jaringan-jaringan tersebut secara sederhana menghubungkan antara sebuah lembaga dan kehidupan bermasyarakat, baik nasional maupun transnasional.

Produktifitas pergerakan hizmet ditandai, setidaknya, dengan jumlah sekolah-sekolah hizmet yang berkembang sangat pesat dan tersebar di banyak negara. Yavuz mengemukakan setidaknya terdapat tiga ratus sekolah, mulai dari Turki ke Siberia dan Filiphina. ${ }^{62}$ Antep bahkan me-

${ }^{58}$ Orhan Akkurt, "Gülen, The Most Important Figure Of Tolerance and Dialogue," Today's Zaman, 25 Juli 2010, 13, http://www.gulenconference.nl/ gc2010/files/ News_FG.pdf (diakses pada tanggal 7 April 2013).

${ }^{59}$ Muhammad A.S. Hikam, "Civil Society and Government Relations in the Post Reformasi Indonesia: Preliminary Observations," 1.

${ }^{60}$ Sukron Kamil, Pemikiran Politik Islam Tematik, 130.

${ }^{61}$ Rasyid mendefenisikan civil society sebagai masyarakat yang memiliki kemandirian, tidak bergantung kepada negara dan memiliki jaringan-jaringan yang produktif.Lihat dalam Sukron Kamil, Pemikiran Politik Islam Tematik, 130.

${ }^{62}$ M. Hakan Yavuz, "Islam and the Secular State: The Gülen Movement," review by: 
nyebutkan bahwa pergerakan Gülen telah mendirikan lebih dari lima ratus sekolah dan enam universitas di sekitar seratus negara. Pergerakan ini juga bergabung dengan koran harian Turki (Zaman), beberapa stasiun TV termasuk Ebru TV di Amerika Serikat, dan sebuah konfederasi dari ribuan pengusaha (TUSKON). ${ }^{63} \mathrm{Hal}$ ini mengambarkan perkembangan pergerakan hizmet di dunia, serta keberadaanya sebagai sebuah civil society transnasional Muslim.

\section{Pergerakan Hizmet di Indonesia}

Salah satu bentuk transnasional pergerakan hizmet adalah keberadaannya Indonesia sejak tahun 1995. Pergerakan ini dibawa oleh Mustofa Kenel, Hakan, dan Abdul Galib. Kebodohan, kemiskinan, dan konflik menjadi tema utama yang mendorong pergerakan ini datang ke nusantara. Mereka mendirikan dan tinggal di dershane serta mendirikan sekolah hizmet untuk pertama kali di Indonesia, yaitu sekolah Pribadi Depok. ${ }^{64}$ Yavuz mengemukakan bahwa pergerakan hizmet telah membangun jaringan transnasional dershane yang kuat sebagai wadah untuk menghasilkan orangorang yang nantinya ikut dan berkontribusi dalam pergerakan hizmet. Sasaran utamanya adalah generasi muda, dengan memberikan stimulus melalui berbagai kegiatan seperti perlombaan, seminar, tour, perjalanan wisata, dan beasiswa.

Dawam Rahardjo dan AS. Hikam mengemukakan demikian, bahwa civil society kebudayaan memang dibangun atas dasar komitmen dan kesukarelaan yang kuat. Pergerakan hizmet memperlihatkan hal ini dalam pergerakannya, sehingga tidak jarang kemudian menarik simpati kalangan muda untuk bergabung dengan pergerakan ini. Wajar bila Cetin mengemukakan bahwa pergerakan hizmet memiliki para pengikut yang dengan sukarela berkontribusi terhadap pergerakan ini. Mereka melakukan berbagai hal tanpa imbalan atau dijanjikan sesuatu.

Tamer Balci, Journal of the American Oriental Society, Vol. 125, No. 2 (Apr. - Jun., 2005), 331333, American Oriental Society Stable, http://www.jstor.org/ stable/20064359. (diakses tanggal 19/03/2012).

${ }^{63}$ Lihat dalam Abdullah T. Antepli, "Contemporary Islamic Converstions: M. Fethullah Gülen on Turkey, Islam, and the West byNevval Sevindi," review by: Ahmet T. KuruVol. 62, No. 3 (Summer, 2008),h.529-530, Middle East Journal, . (diakses tanggal 19/03/2012).

${ }^{64}$ Wawancara dengan Ali Ünsal, direktur Fethullah Gülen Chair, pada tanggal 7 Mei 2013 di sekretariat Fethullah Gülen Chair. 
Persaudaraan merupakan salah satu ciri dari civil society seperti yang dikemukakan oleh Tocqueville, Hikam, dan Riyas Rasyid. Ini menjadi sarana strategis dalam peningkatan kerja sama dalam bidang bisnis guna meningkatkan ekonomi. Bidang bisnis sekaligus menjadi sebuah sarana bagi pergerakan hizmet untukmendukung misi kemanusiaan yang diembannya. Lebih lanjut, setiap perusahaan dapat berkontribusi dalam misi kemanusiaan melalui berbagai program bantuan kemanusiaan, pendidikan, sosial, agama, dan lainnya. Pernyataan Yavuz menjadi sesuatu yang patut dipertimpertimbangkan bahwa pergerakan hizmet didukung oleh jaringan bisnis yang kuat. ${ }^{65}$ Mereka mendukung berbagai program yang dijalankan oleh pergerakan ini, seperti perjalanan ke Turki, kamp musim panas, dan sekolah.

Salah satu jaringan pebisnis yang dibangun oleh pergerakan hizmet di Indonesia adalah Turkish Indonesian Trade Association (TITA) yang berdiri pada tahun 2008. Lembaga ini adalah sebuah perkumpulan bisnis yang mewakili ketertarikan para pelaku bisnis sektor swasta terhadap hubungan komersial/bisnis antara Indonesia dan Turki. TITA berafiliasi kepada Kamar Dagang dan Industri Indonesia (KADIN) komite di Jakarta dan konfederasi pelaku bisnis dan industri (TUSKON) di Turki. ${ }^{66}$ Meski lembaga ini didirikan guna mendukung hubungan ekonomi kedua negara, melalui perdagangan dan transaksi bisnis, namun tetap saja program pergerakan hizmet di Indonesia mendapat dukungan yang kuat darinya.

Pernyataan Ryas Rasyid menjadi penting dalam menanggapi hal ini, bahwa menurutnya civil society kebudayaan memang memiliki jaringanjaringan yang produktif, seperti pergerakan hizmet memiliki yang jaringan bisnis yang kuat. ${ }^{67}$ Jaringan-jaringan produktif ini mendukung penuh apa yang dilakukan oleh pergerakan hizmet melalui sokongan dana yang tidak sedikit. Pergerakan hizmet melalui TITA juga menggambarkan bahwa adanya hubungan antara pemerintah dengan civil society pada hal-hal yang

${ }^{65}$ M. Hakan Yavuz, "Nasil bir Thrkiye" (What Type of Turkey?), Milliyet (Istanbul), (11 August 1997), dalam M. Hakan Yavuz, "Towards an Islamic Liberalism?: The Nurcu Movement and Fethullah Gülen," h. 604.

${ }^{66}$ TITA, "Tentang Tita," http://www.tita.or.id/index.php/tentangtita (diakses pada tanggal 22 Mei 2013).

${ }^{67}$ Sukron Kamil, Pemikiran Politik Islam Tematik: Agama dan Negara, Demokrasi, Civil Society, Syariah dan HAM, Fundamentalisme dan Anti Korupsi (Jakarta: Kencana, 2013), h. 130. 
bersifat publik, sehingga civil society tidak hanya mampu menjadi antitesis bagi negera tetpi juga dapat bermitra dengannya.

Kelembagaan hizmet di Indonesia juga diwujudkan dalam bentuk dialog. Langkah ini lebih mengarah kepada apa yang dilakukan oleh Fethullah Gülen dalam menjelaskan tentang toleransi, cinta, dan kemanusiaan antar umat manusia. Bentuk dialog ini dilakukan sejak lama, puncaknya dalam dialog antar umat beragama, dilakukan pertama kali oleh Fethullah Gülen pada tahun 2001 yang mana ia berdialog dengan Paus Yohanes Paulus II di Vatikan. ${ }^{68}$ Dialog ini juga dilakukan oleh pergerakan hizmet yang ada di Indonesia dengan berbagai kalangan, seperti ormas, termasuk Nahdatul Ulama (NU) dan Muhammadiyah, tokoh masyarakat, cendikiawan, dan pemerintah melalui kementerian agama dan lembaga lain. Ini tidak terlepas dari tujuan pergerakan hizmet yang disebutkan oleh Fethullah Gülen dalam bukunya Islam Rahmatan lil Alamin, bahwa tujuannya adalah untuk memperoleh Ridâ Allah Swt. ${ }^{69}$ Islam sebagai agama yang memberi rahmat tidak hanya kepada umat Muslim tetapi juga sekalian alam.

Pergerakan hizmet di Indonesia, meski telah melakukan dialog, namun belum mengembangkan konsep dialog sebagaimana yang digagas oleh Gülen, walaupun Yunus Emre telah muncul sebagai sebuah lembaga yang membidanginya. Lembaga yang juga memiliki fungsi yang hampir sama dan berkembang sebagai salah satu lembaga dialog adalah Fethullah Gülen Chair (FGC), berdiri sejak tahun 2009 di UIN Syarif Hidayatullah Jakarta, ${ }^{70}$ setelah sebelumnya ada di beberapa negara seperti Australia dan

\footnotetext{
${ }^{68}$ Muhammad Fethullah Gülen, Bangkitnya Spiritualitas Islam, terj. Fuad Saefuddin(Jakarta: Republika, 2013), XVIII.

${ }^{69}$ Ridâ yang dimaksud adalah pemberian dari Allah SWT. sehingga Ia tidak akan murka kepada sang penerima untuk selamanya. M. Fethullah Gülen, Islam Rahmatan lil Alamin, trans. Fauzi A. Bahreisy (Jakarta: Republika, 2011), 302. Hal yang sama juga sampaikan Ali Ünsal, direktur Fethullah Gülen Chair, dalam seminar Coexistence of Civilizations and The Role of "Hizmet" Between East and West, 30 Nopember 2011 di Auditorium Harun Nasution UIN Jakarta. Lebih lanjut dijelaskan oleh Togoslu yang menyatakan bahwa tujuan semua pembangunan dan prestasi dipertimbangkan sebagai sebuah pencaharian demi Tuhan. Erkan Togoslu, "Hizmet: from Futuwwa Tradition to the Emergence of Movement in Public Space", 15 November 2008, Fethullah Gülen Chair, dalam www.fethullahGülenchair.com (diakses tanggal 9 November 2011).

${ }^{70}$ Editorial, "Fethullah Gülen Chair," Fethullah Gülen Chair Bulletin, Agustus-SeptemberOktober (2011), 3. Lembaga ini merupakan sebuah lembaga yang lahir sebagai langkah konkrit terciptanya perdamaian dunia, mengusung terselenggaranya dialog antar agama dan budaya, menjunjung tinggi filantropi dan pengabdian pada sesama.
} 
Belgia. Ini berawal dari sebuah konferensi yang diadakan di Belanda dan House of Lord di London, Inggris. Para pelaku pergerakan hizmet berhasil menyita perhatian masyarakat Barat melalui konferensi tersebut. Ini pula yang membawa Fethullah Gülen Chair didirikan di Universitas Katolik Australia. Selain konferensi, studi terhadap pergerakan hizmet diterbitkan oleh Universitas Utah, ${ }^{71}$ juga langkah Gülen melakukan dialog dengan tokoh Kristen, Paus Yohanes Paulus II di Vatikan tahun 2001, berakibat pada diterimanya pemikiran Gülen di dua universitas di Australia dan Belgia. $^{72}$

Bentuk dialog yang dilakukan oleh FGC tidak hanya secara lisan melainkan juga tertuang dalam pendekatan personal-kelembagaan melalui program perjalanan wisata yang diikuti oleh para akademisi, petinggi birokrasi, rektor, direktur institut, hingga dewan pertimbangan presiden ke beberapa negara seperti Turki, Vietnam, Brunei Darussalam, Kamboja, Australia, Malaysia, Amerika, Yordania, dan Thailand. ${ }^{73}$ Kunjungan ke Turki tersebut mengunjungi lokasi-lokasi bersejarah dan lembaga-lembaga hizmet, seperti mengunjungi Koran terbesar di Turki "Zaman", Universitas Fatih, Semanyolu TV, dan Gazeteciler ve Yazarlar Vakfi (Yayasan Jurnalis dan Penulis). ${ }^{74}$ Meski hal ini pada satu sisi dianggap sebagai upaya untuk mensosialisasikan ideologi hizmet, namun dalam tataran civil society kebudayaan hal ini dianggap sebagai sebuah cara untuk memenuhi kebutuhan konstituennya.

Hal ketiga yang dilakukan oleh pergerakan hizmet sebagai civil society budaya tertuang dalam bidang pendidikan. Pacific Countries Social and Economic Solidarity Association atau yang lebih dikenal dengan sebutan PASIAD yang beridiri di Indonesia sejak tahun 1990-an adalah lemabaga yang membidangi hal ini. PASIAD mendirikan beberapa sekolah dalam bentuk mitra kerja yaitu di Aceh, Tangerang Selatan, Depok, Semarang,

71 "TURKEY: Fethullah Gulen promotes a modern Islam," Oxford Analytica Daily Brief Service, (18 Januari 2008), http://e-resources.pnri.go.id:2058/docview/192450464/13E111F45761 1 FF80D4/1 ?accountid $=25704$ (diakses pada tanggal 16 Mei 2013)

72 "TURKEY/INT: Gulen movement faces more global scrutiny," Oxford Analytica Daily Brief Service, (4 Feruari 2011), http://e-resources.pnri.go.id:2058/docview/849229679/13E111F45 7611FF80D4/2? accountid=25704 (diakses pada tanggal 16 Mei 2013)

${ }^{73}$ Editorial, "Studi Tour ke Thailand, Kamboja, dan Vietnam," Fethullah Gülen Chair Bulletin, Februari, Maret, April (2011), h.17.

${ }^{74}$ Baca dalam Editorial, "Tour ke Turki," Fethullah Gülen Chair Bulletin, Mei, Juni Juli, (2011), 13. 
Bandung, Seragen, dan Yogyakarta. ${ }^{75}$ Setiap sekolah memiliki lebih dari 600 orang siswa sebagaimana pada sekolah Kharisma Bangsa di Tangerang Selatan yang memiliki jumlah siswa sebanyak 600 orang lebih dengan rata-rata siswa perkelas sebanyak 20-25 orang. ${ }^{76}$ Ini memperlihatkan bahwa sekolah-sekolah mitra kerja PASIAD mudah diterima oleh banyak kalangan, selain keberhasilan pergerakan hizmet dalam mendirikan lebih dari tiga ratus sekolah, mulai dari Turki hingga ke Siberia dan Filiphina. ${ }^{77}$ Lebih lanjut hal ini sekaligus memberi penjelasan bahwa civil society merupakan masyarakat mandiri yang menempati ruang (space), sehingga dalam kepentingan bersama menjadi mitra bagi negara, ${ }^{78}$ sesuai pendapat Dawam Rahardjo dan AS. Hikam.

Melihat berbagai lembaga kemanusiaan hizmet di atas, maka ini sesuai dengan teori civil society dengan tipologi kebudayaan yang dikemukakan oleh Alexis de' Tocqueville, ${ }^{79}$ serta Muhammad As. Hikam, bahwa civil society merupakan area yang di dalamnya terdapat kehidupan sosial yang terorganisasi dan memiliki ciri-ciri yang khas, seperti kesukarelaan, persaudaraan, swasembada, swadaya, dan kemandirian yang tinggi, apalagi

${ }^{75}$ Sekolah-sekolah tersebut di antaranya adalah Lembaga Pendidikan Pribadi Depok, Pribadi Bilingual Boarding School Bandung, Fatih Bilingual School Fatih, Lembaga Pendidikan Semesta, Fatih Bilingual School Banda Aceh, Kharisma Bangsa School of Global Education, Bilingual Boarding School Seragen, Kesatuan Bangsa School Yogyakarta. Lihat PASIAD Indonesia, "Sekolah Mitra Kerja PASIAD", http://www.pasiadindonesia.org/index.php/sekolah-mitra-kerja-pasiad (diakses pada tanggal 29 April 2013).

${ }^{76}$ Dialog singkat dengan Mustofa, 29 Mei 2013 di Kharisma Bangsa pada acara studi banding badan eksekutif mahasiswa fakultas Ushuluddin IAIN Sumatera Utara.

${ }_{77}$ M. Hakan Yavuz, "Islam and the Secular State: The Gülen Movement", review by: Tamer Balci, Journal of the American Oriental Society, Vol. 125, No. 2 (Apr. - Jun., 2005), 331-333, American Oriental Society Stable, . (diakses tanggal 19/03/2012). Lebih lanjut Antepli menyebutkan pergerakan Gülen telah mendirikan lebih dari lima ratus sekolah dan enam universitas di sekitar seratus negara. Pergerakan ini juga bergabung dengan koran harian Turki (Zaman), beberapa stasiun TV (termasuk Ebru TV di Amerika Serikat), dan sebuah konfederasi dari ribuan pengusaha (TUSKON). Lihat dalam Abdullah T. Antepli, "Contemporary Islamic Converstions: M. Fethullah Gülen on Turkey, Islam, and the West byNevval Sevindi," review by: Ahmet T. Kuru, Middle East Journal, Vol. 62, No. 3 (Summer, 2008), 529-530, Middle East Institute, http://www.jstor.org/stable /25482552. (diakses tanggal 19/03/2012).

${ }^{78}$ Hikam menjelaskan bahwa sebenarnya negara adalah hasil karya dari masyarakat, bukan sebaliknya. Pembagian peran dan fungsi baru terjadi ketika masyarakat sudah semakin modern, sehingga semakin jelas bahwa masyarakat sambil mencoba mengontrol apa yang terjadi di wilayah negara. Muhammad A.S. Hikam, Islam, Demokratisasi, dan Pemberdayaan Civil Society (Jakarta: Erlangga, 2000), h. 82.

${ }^{79}$ Sukron Kamil, Pemikiran Politik Islam Tematik, h. 130. 
bila berhadapan dengan negara. ${ }^{80}$ Kegiatan-kegiatan yang dilakukan oleh lembaga-lembaga hizmet tidak bergantung kepada negara, meski mereka menjadi lembaga yang menjembatani hubungan antara kedua negara, yakni Turki dan Indonesia. Hal ini disebabkan civil society kebudayaan lebih mengedepankan kepentingan komunal yang bersifat umum dari pada hubungan yang struktural dengan negara.

\section{Kebudayaan sebagai Fokus Pergerakan Hizmet di Indonesia}

Melihat apa yang dilakukan oleh pergerakan hizmet di Indonesia terlihat bahwa pergerakan ini memfokuskan diri pada hal-hal yang bersifat kebudayaan, sehingga pergerakan ini menjadi civil society budaya. Hal ini dilakukan dalam upaya membangun kemandirian ekonomi melalui pemberdayaan kelas menengah, dialog sebagai resolusi konflik dan kritisisme melalui pendidikan. Kritisisme dapat dilihat dari kemampuan pergerakan ini dalam mendirikan sekolah-sekolah bertaraf internasional yang tersebar di beberapa daerah di Indonesia, seperti Depok, Banda Aceh, Bandung, Tangerang Selatan, Yogyakarta, dan Semarang. ${ }^{81}$ Selain itu, pergerakan ini juga membangun lembaga bimbingan belajar, lembaga hubungan antar perguruan tinggi, serta tempat tinggal bagi mahasiswa dan pelajar. Lebih lanjut dalam upaya membangun kritisisme tersebut, pergerakan hizmet juga melakukan berbagai macam program, di antaranya olimpiade sains dan teknologi internasional, olimpiade bahasa, dan olimpiade matematika bagi para siswa sekolah menengah pertama dan menengah atas, serta kursus bahasa.

Dialog sebagai resolusi konflik dilakukan oleh pergerakan hizmet sebagai sebuah langkah untuk mewujudkan persaudaraan. Langkah ini di Indonesia dilakukan dengan berbagai kalangan seperti NU, Muhammadiyah, para petinggi pemerintahan, dan akademisi. Sayangnya, dialog yang dilakukan oleh pergerakan hizmet masih terbatas pada internal umat Muslim dalam bentuk seminar maupun konferensi, belum meluas hingga kalangan eksternal, yaitu umat agama lain. Hal ini yang masih

${ }^{80}$ Muhammad A.S. Hikam, "Civil Society and Government Relations in the Post Reformasi Indonesia: Preliminary Observations,” Usindo Brief, (19 Januari 2010), h.1, http://usindo.org/wpcontent/uploads/2010/08/Hikam-Brief-Final.pdf (diakses pada tanggal 10 Januari 2013).

${ }^{81}$ Lihat "Sekolah Mitra Kerja PASIAD,"dalam http://www.pasiadindonesia.org/index.php/ sekolah-mitra-kerja pasiad (diakses pada tanggal 29 April 2013). 
menjadi problem bagi pergerakan hizmet dalam upaya resolusi konflik antar penganut agama. Lebih dari itu, kemampuan dialog yang dimiliki oleh civil society menunjukkan kemampuannya dalam menjalin kerjasama, tidak hanya dengan kalangan internal atau sesama civil society yang bernuansa homogen melainkan juga ketika berhadapan dengan negara. Oleh sebab itu, semakin berkualitas dialog yang dibangun oleh civil society dan melibatkan berbagai pihak, maka hasil yang akan dicapai juga akan lebih besar.

Pergerakan hizmet berupaya untuk melakukan pembentukan kultur masyarakat agar masyarakat dapat berdialog dan memberikan resolusi terhadap berbagai konflik yang terjadi, meski dialog yang dilakukan oleh pergerakan hizmet di Indonesia baru sebatas kepada sesama Muslim. Civil society ini berupaya untuk menanamkan nilai-nilai bagi masyarakat. Layaknya sebuah civil society kebudayaan, pergerakan hizmet berorientasi kepada nilai-nilai keagamaan, berupaya mementingkan kepentingan komunal, bersifat dialogis, serta hal lain sebagaimana yang dikemukakan oleh de' Toqueville, Nurcholis Madjid, AS. Hikam, Ryas Rasyid, dan Dawam Rahardjo.

Melihat berbagai penjelasan di atas bila dianalisis melalui teori civil society, maka akan terlihat bahwa pergerakan hizmet merupakan gerakan civil society Muslim yang fokus terhadap budaya. Hal ini berbeda dengan apa yang dikemukakan oleh al-Mawardi, al-Baqillani, Abu Ya'la al-Farra, al-Farabi, dan Ibn Thaimiyah bahwa civil society memiliki kaitan yang jelas dengan kepemimpinan, sehingga membicarakan civil society dalam sejarah Islam akan berkaitan erat, bahkan secara struktural dengan negara. Pergerakan hizmet memperlihatkan hal yang berbeda, yaitu bersifat kebudayaan, sebagaimana yang dijelaskan oleh Ibnu Khaldun sebagai hadarah dan Nurcholis Madjid sebagai masyarakat madani. Lebih jauh, hal ini membuktikan bahwa civil society dalam dunia muslim juga berbicara pada konteks komunal tidak hanya yang dialektis dalam berhubungan dengan negara.

Konsep ummah adalah bentuk nyata yang diajakarkan dalam doktrin Islam. Ini memperlihatkan kepentingan komunal tidak hanya ekslusif umat Muslim semata, melainkan juga umat agama lain. Pergerakan hizmet melalui doktrin cinta dan toleransi bupaya untuk menjadikan manusia dalam satu ikatan yang sama, yang dalam Islam disebut ummah. 
Konsep ini bila dilihat dari kacamata civil society kebudayaan sangat kental dengan nilai-nilai persaudaraan, kepercayaan, dan peradaban. Pergerakan hizmet melalui pemahaman konsep ini melakukan apa yang mereka sebut sebagai tindakan positif melalui tindakan kolektif. Tindakan kolektif inilah nantinya yang dapat menyelesaikan persoalan yang mereka anggap sebagai musuh bersama, yaitu kebodohan, kemiskinan, dan konflik. Wujud dari semua ini adalah tindakan nyata melalui kelembagaan hizmet yang diperuntukkan khusus untuk menangani hal tersebut.

Melihat fokus yang dilakukan oleh pergerakan hizmet, maka dapat terlihat bahwa pergerakan ini tidak memiliki hubungan yang struktural dengan negara. Ini seperti yang dikemukakan oleh Ernest Gellner (19251995) yang mana civil society tidak memiliki hubungan strukrutal dengan negara, sehingga berdiri secara otonom. ${ }^{82}$ Ia adalah sekelompok masyarakat yang mandiri terhadap negara, ${ }^{83}$ terhubung melalui jaringanjaringan yang produktif, ${ }^{84}$ dan hanya membutuhkan ruang gerak yang disebut dengan ruang publik. Pergerakan hizmet membuktikan hal tersebut melalui berbagai kegiatan yang berorientasi pada kepentingan publik.

Civil society ini memiliki pola kebudayaan yang hanya mengedepankan prinsip-prinsip kultural seperti kepentingan umum, ideologi, dan agama. Fokus pergerakan hizmet pada pendidikan, dialog, sosial, dan ekonomi menggambarkan misi kemanusiaan yang diembannya. Ini sekaligus membawa banyak perubahan dalam berbagai lini. Ideologi yang dipergunakan untuk kepentingan publik, cepat atau lambat, akan diserap oleh publik, sehingga publik dengan sendirinya akan menjalankan apa yang mereka sebut dengan kepentingan bersama. Lebih lanjut, ini menggambarkan bahwa Islam sebagai agama yang universal dan salah satu sumber kebudayaan memiliki kontribusi dalam penguatancivil society, dan dibuktikan melalui konsep ummah (persaudaraan) yang tertuang

${ }^{82}$ Brendan O'leary, "On the Nature of Nationalism: An Appraisal of Ernest Gellner's Writings on Nationalism," Cambridge University Press, GreatBritainB.J.Pol.S.27,(1997),h.191,http://www. polisci.upenn.edu/ppec/PPEC\%20People/Brendan\%20O'Leary/publications/Journal\%20Articles/ Oleary_BJPS_Appraisal_Gellner.pdf (diakses pada tanggal 8 Januari 2013).

${ }^{83}$ Muhammad A.S. Hikam, "Civil Society and Government Relations in the Post Reformasi Indonesia: Preliminary Observations," h. 1.

${ }^{84}$ Pernyataan ini dikemukakan oleh M. Riyas Rasyid. Lihat dalam Sukron Kamil, Pemikiran Politik Islam Tematik, h.130. 
dalam doktrin normatif Islam. Islam menjadikan agama yang tidak hanya berbicara pada tataran transendental, melainkan juga berbicara pada tataran konsep khususnya konsep civil society. Hal ini membuktikan bahwa agama, yang dalam hal ini adalah Islam, menjadi media yang berperan penting dalam memper lebar ruang publik dan berada dalam posisi yang sejalan dengan civil society.

\section{Penutup}

Islam merupakan agama yang menjadi salah satu sumber budaya berkontribusi dalam penguatan civil society, sehingga agama menjadi media yang berperan penting dalam memperlebar ruang publik dan berada dalam posisi yang sejalan dengan civil society.

Kebenaran kesimpulan ini didukung oleh sejumlah temuan terkait dengan objek penelitian, yaitu pergerakan hizmet di Indonsia sebagai salah satu civil society Muslim. Pertama, pergerakan hizmet di Indonesia sebagai sebuah gerakan civil society transnasional yang mengusung tematema Islam muncul dan berkembang di Indonesia dengan menggunakan pendekatan budaya sebagai agenda kolektif mereka. Pergerakan ini memiliki kemandirian ekonomi melalui himpunan para pebisnis, meningkatkan budaya kritisis memelalui pendidikan, dan menjadikan dialog sebagai sarana bagi resolusi konflik dan persaudaraan.

Kedua, pergerakan hizmet merupakan gerakan yang berideologi hizmet(pelayanan), yaitui deologi yang mengadopsi nilai-nilai Islam. Ideologi ini dipopulerkan oleh FethullahGülen dan diikuti oleh orangorang yang terinspirasi oleh pemikirannya, kemudian mendirikan sebuah pergerakan civil society kebudayaan yang dikenal dengan pergerakan hizmet. Ideologi ini mengedepankan kebodohan, kemiskinan, dan konflik sebagai musuh bersama yang harus diperangi.

Ketiga, kebodohan, kemiskinan, dan konflik menjadi acuan tersendiri bagi pergerakan hizmet dalam menjalankan gerakan pelayanan demi kemanusiaan. Pergerakan transnasional ini kemudian mendirikan lembagalembaga kemanusiaan. Ini sekaligus menjadi model tersendiri dan menjadi ciri khas pergerakan yang mengedepankan dialog dantoleransi. Di Indonesia, pergerakan ini telah mendirikan lembaga-lembaga pendidikan, lembaga sosial, lembaga ekonomi, dan hubungan antar perguruan tinggi. Mereka tergabung dalam PASIAD Indonesia, Turkish Indonesian Trade 
Association (TITA), Fethullah Gülen Chair, dan dershane. Eksistensi pergerakan ini semakin meningkat dan dapat dilihat dari penyebarannya yang telah mendirikan lembaga-lembaga kemanusiaan di kota-kota besar di Indonesia. Ini menjadi upaya pergerakan hizmet dalam membanguncivil societybudaya di Indonesia, dan sekaligus membuktikan bahwa Islam sejalan dengan civil society.

\section{Pustaka Acuan}

Alam, Bachtiar. "Antropologi dan Civil Society: Pendekatan Teori Kebudayaan." Antropologi Indonesia Th. XXIII No. 60 SeptemberDesember 1999.

Akkurt, Orhan. "Gülen, The Most Important Figure Of Tolerance and Dialogue." Today's Zaman, 25 Juli 2010, 13, http://www. gulenconference.nl/gc2010/files/News_FG.pdf diakses pada tanggal 7 April 2013.

Antepli, Abdullah T. "Contemporary Islamic Converstions: M. Fethullah Gülen on Turkey, Islam, and the West byNevval Sevindi," review by: Ahmet T. KuruVol. 62, No. 3 (Summer, 2008), 529-530,Middle East Journal, diakses tanggal 19/03/2012.

Bakti, Andi Faisal. "On the Concept of Civil Society or Masyarakat Madani and Paramadina." http://www.andifaisalbakti.com/wpcontent/uploads/2012/04/On-the-Concept-of-Civil-Society-orMasyarakat-Madani-and-Paramadina.pdf diakses pada tanggal 26 Juli 2013.

Bilici, Mucahit. "The Fethullah Gülen Movement and Its Politics of Representation in Turkey." The Muslim World 96. 1 Januari 2006,http://eresources.pnri.go.id:2058/docview/216435705/fulltext $\mathrm{PDF} / 13 \mathrm{D} 1 \mathrm{ECA} 416 \mathrm{C} 18 \mathrm{E} 38 \mathrm{ADF} / 1$ ?accountid=25704 diakses pada tanggal 30 Maret 2013.

Bruckmayr, Philipp. "Fethullah Gülen and Islamic Literary Tradition." Islam in the Age of Global Challenges--Conference Proceedings, 17 November 2008, http://medya.zaman.com.tr/2008/11/17/ bruckmayr.pdf diakses pada tanggal 20 Maret 2013.

Culla, Adi Suryadi. Rekonstruksi Civil Society Wacana dan Aksi Ornop di Indonesia. Jakarta: LP3ES, 2006. 
Culla, Adi Suryadi. Masyarakat Madani: Pemikiran, Teori dan Relevansinya denganCita-cita Reformasi. Jakarta: Raja Grafindo Persada, 1999. cet. II.

Donaldson, Mike. "Gramsci, Class and Post-Marxism." International Gramsci Journal No. 1 (Juli 2008), 5-18. http://www.uow.edu. au/content/groups/public/@web/@arts/@gramsci/documents/doc/ uow136956.pdf diakses pada tanggal 5 Maret 2013.

Enayat, Hamid. Modern Islamic Political Thought. Kuala Lumpur: The Macmillan Press, 2001.

Gülen, M. Fethullah. Bangkitnya Spriritualitas Islam. terj. Fuad Saefuddin. Jakarta: Republika, 2012.

Gülen, M. Fethullah. Islam Rahmatan lil Alamin. trans. Fauzi A. Bahreisy. Jakarta: Republika, 2011.

Greaves, Nigel. "Resisting Abstraction: Gramsci’s Historiological Method." International Gramsci Journal No. 3 (Maret 2011, 39, http://www. uow.edu.au/arts/ research/gramsci-journal/ diakses pada tanggal 5 Maret 2013.

Habermas, Jürgen. Between facts and norms: Contributions to a discourse theory of law and democracy. Cambridge: MIT Press, 1996.

Hadi, Syamsul. "Perkembangan Wacana Civil Society." CIVIC Journal For Civil Society Empowerment vol. 1 no.3 Desember 2003.

Hendrick, Joshua D. "Global Islam and the Modern World: Transnational Muslim Social Movements and the Movement of Fethullah Gülen, a Comparative Approach," dalamIslam in the Contemporary World-2 New Jersey: Tughra Books, 2009, 124.

Hikam, Muhammad A.S. "Civil Society and Government Relations in the Post Reformasi Indonesia: Preliminary Observations." Usindo Brief, (19 Januari 2010), http://usindo.org/wp-content/uploads /2010/08/ Hikam-Brief-Final.pdf diakses pada tanggal 10 Januari 2013.

Hikam, Muhammad A.S. Islam, Demokratisasi, dan Pemberdayaan Civil Society. Jakarta: Erlangga, 2000.

Huwaidi, Fahmi. Demokrasi dan Masyarakat Madani, terjemahan dari al-Islam wa al-Dimu Qrathiyyah. Bandung: Mizan, 1996.

Iqbal, Muhammad. Figh Siyasah: Kontekstualisasi Doktrin Politik Islam. Jakarta: Gaya Media Pratama, 2007. 
Islamoglu, H. "Civil Society/Public Sphere: History of the Concept." International Encyclopedia of the Social \& Behavioral Sciences: Elsevier Science, 2001, 1897, http://www.nyu.edu/ipk/calhoun/files/ calhounCivilSocietyPublicSphereHistoryOfConcept.pdf, diakses pada tanggal 22 Januari 2013.

Juhri, Syarifuddin. 1 Abad Muhammadiyah Gagasan Pembaruan Sosial Keagamaan. Jakarta: Kompas, 2010.

Kamil, Sukron. Pemikiran Politik Islam Tematik: Agama dan Negara, Demokrasi, Civil Society, Syariah dan HAM, Fundamentalisme dan Anti Korupsi. Jakarta: Kencana, 2013.

Kamali, Masoud. "Civil Society and Islam: a Sociological Perspective." Archives Européennes de Sociologie 42. 3 Desember 2001, 479,http:// eresources.pnri.go.id:2058/docview/216940878/fulltextPDF/13D0 96BA4AD2C1F726D/1 ?accountid=25704 diakses pada tanggal 4 Maret 2013.

Keane, J. Civil Society and the State. London: Verso, 1988

Khan, Muhammad Zubair. dkk., "From Habermas Model to New Public Sphere: A Paradigm Shift." Global Journal of Human Social Science Volume 12 Issue 5 Version 1.0 (Maret 2012), http:// socialscienceresearch.org/index.php/GJHSS/article/view/312/271 diakses pada tanggal 31 Desember 2012.

Martinez, Patricia A. "The Islamic state or the state of Islam in Malaysia." Contemporary Southeast Asia; (Desember 2001). http://e-resources. pnri.go.id:2058/docview/205217493/ fulltextPDF/13D0561442C4 A69581E/3?accountid=25704 diakses pada tanggal 25 Maret 2013.

Mayo, Peter. "The Centrality of the State in Neoliberal Times: Gramsci and beyond." International Gramsci Journal No. 3 (Maret 2011), http://www.uow.edu.au/arts/research/gramsci-journal/ diakses pada tanggal 5 Maret 2013.

Putra, Yudha Manggala P. "Pakar Barat: Turki Contoh Ideal bagi Dunia Islam.” Republika Online, http://www.republika.co.id/berita/ dunia-islam/islam-mancanegara/12/05/02/m3e7yp-pakar-barat-turkicontoh-ideal-bagi-dunia-islam diakses pada tanggal 11 Nopember 2012.

O'leary, Brendan. "On the Nature of Nationalism: An Appraisal of 
Ernest Gellner's Writings on Nationalism." Cambridge University Press, Great Britain B.J.Pol.S. 27, (1997), http://www.polisci.upenn. edu/ppec/PPEC\%20People/Brendan\%20O'Leary/publications/ Journal\%20Articles/Oleary_BJPS_Appraisal_Gellner.pdf diakses pada tanggal 8 Januari 2013.

Singh, Vijender. "An Analysis of Concept and Role of Civil Society in Contemporary." India Global Journal of Human Social Science, Volume 12 Issue 7 Version 1.0 (April 2012). http://socialscienceresearch.org/ index.php/GJHSS/article/view/340/298 diakses pada tanggal 31 Desember 2012.

Smith, Kylie. "Gramsci at the margins: subjectivity and subalternity in a theory of hegemony." International Gramsci Journal No. 1, 2 (April 2010).http://www.uow.edu.au/content/groups/public/@web/@ arts/@gramsci/documents/doc/uow134747.pdf (diakses pada tanggal 3 Maret 2013).

Smith, Jackie. Charles Chatfield, and Ron Pagnucco, edt. Transnational Social Movements and Global Politics, New York: Syracus University Press, 1997

Sukron Kamil, "Korupsi sebagai Persoalan Kebudayaan: Mencari Akar Masalah Korupsi di Indonesia dan Solusinya." dalam Korupsi mengorupsi Indonesia: sebab, akibat, dan prospek pemberantasan, edt. Wijayanto dan Ridwan Zachrie. Jakarta: PT Gramedia Pustaka Utama, 2009.

Sunarto, Ahmad. Kamus Alfikr. Surabaya: Halim Jaya, 2007. cet. III.

Sulistyo, Dermawan. Keamanan Negara, Keamanan Nasional dan Civil Society. Jakarta: Pensil, 2009.

Vahide, Sükran. Biografi Intelektual Bediuzzaman Said Nursi: Transformasi Dinasti Utsmani Menjadi Republik Turki. Jakarta: Anatolia,2007.

Yaman, Mine. "Civil Society and Democratic Consolidation: the Case of Tusiad." (Tesis Bilkent University: Ankara, 2002), 3, http://www. thesis.bilkent.edu.tr/0002069.pdf diakses pada tanggal 16 Januari 2013.

Yavuz, M. Hakan. "Islam and the Secular State: The Gülen Movement." review by: Tamer Balci, Journal of the American Oriental Society, Vol. 125, No. 2 (Apr. - Jun., 2005), 331-333, American Oriental 
Society Stable.http://www.jstor.org/stable/20064359. Diakses tanggal 19/03/2012.

Younkins, Edward W. "Hegel's Authoritariant State as the Divine Idea on Earth.” Le Quebecois Libre, Montreal (15 November 2005), http:// www.quebecoislibre.org/05/051115-11.htm diakses pada tanggal 16 Januari 2013. 